\title{
"Mulatismo musical" e sua simbologia: uma revisão historiográfica do Padre José Maurício Nunes Garcia a partir da etnomusicologia
}

\author{
Pedro Razzante Vaccari \\ Departamento de Música, \\ Universidade Estadual Paulista -UNESP, Brasil
}

DOI: https://doi.org/10.31492/2184-2043.RILP2020.37/pp.47-72

\begin{abstract}
Resumo
Trata de uma revisão historiográfica a respeito do compositor negro brasileiro Padre José Maurício Nunes Garcia, e como utilizar essa historiografia para aprimorar os estudos sobre ele, com a ferramenta metodológica da Etnomusicologia, a Antropologia. Os objetivos são empreender uma contextualização antropológica e histórica, através da qual sua vida adquiriu contornos até então impensados, uma simbologia histórica enquanto propulsora do movimento abolicionista. Através de fundamentos históricos e sociais pretende-se delimitar o ambiente em que ele foi criado, suas influências socioculturais formadoras e o contexto do Brasil colonial escravocrata. Descobriu-se quão necessária foi sua figura para a consolidação do chamado "mulatismo musical" no Brasil e ascensão do negro dentro da História nacional. A partir de Sérgio Buarque e a transposição de elementos europeus ao Brasil identificamos traços na sua obra que seriam da mesma ordem - muitas de suas características musicais foram importadas da Europa diretamente, sem considerar as idiossincrasias nacionais.
\end{abstract}

Palavras-chave: etnomusicologia; historiografia; "mulatismo musical"; Padre José Maurício Nunes Garcia; simbologia histórica.

\begin{abstract}
It deals with a historiographical revision regarding the Brazilian black composer Father José Maurício Nunes Garcia. The focus is set on how the Historiography, in association with Anthropology, which is the methodological tool of Ethnomusicology can improve the studies on him. The purpose here is to determine the anthropological and historical situations, facts and circumstances in the Master Father's life that took him on an adventitious path to a historical symbolism to finally serve as a driver of the future Abolitionist Movement that took place late in the 19th Century. Taking both historical and social angles, we intend to delimit the environment in which the Father composer was raised, his possible social and cultural influences, and the broad context of the Colonial Brazil under Slavery. With this in mind, we were able to determine the significance of Father José Maurício Nunes Garcia's figure in consolidating the so-called Brazilian musical mulatismo, and the manumission and rise of black men in the national History. Sérgio Buarque show us how European elements that were directly transposed to Brazil reveal similar characteristics in Father José Maurício's work that were imported from Europe to the letter, with no consideration of national idiosyncrasies.
\end{abstract}

Keywords: ethnomusicology; Father José Maurício Nunes Garcia; historical symbolism; historiography; musical mulatismo.

\section{Introdução}

Este artigo busca revisitar, sob o prisma etnomusicológico, a historiografia sobre o compositor negro brasileiro Padre José Maurício Nunes Garcia (17671830). Abrange-se, portanto, desde os primeiros escritos sobre o músico, que datam ainda do Século XIX, na figura do político, jornalista, pintor, escritor, poeta e historiador da Arte Manuel de Araújo Porto Alegre (1806-1879), até 
artigos relativamente recentes, como de Leoni (2010), Historiografia musical e hibridação racial, de Machado (2012), O “mulatismo musical”: processos de canonização na historiografia musical brasileira. Também trata de uma continuidade do que foi exposto em meus artigos Padre José Maurício Nunes Garcia e o mulatismo musical: embranquecimento histórico? (Vaccari, 2018), e The Hegemony of the Europeanism in the Work of José Mauricio Nunes Garcia (Kerr, Vaccari, 2019).

Começamos com Porto Alegre porque é de sua autoria a primeira menção historiográfica ao compositor que se conhece até o momento, em um artigo intitulado "Ideias sobre música", na revista Nitheroy, publicada em Paris em 1836, ou seja, seis anos após a morte de José Maurício (Porto Alegre, 1836).

Curioso notar que durante a sua vida e ainda quase uma década póstuma nenhum escritor ou jornalista tenha, efetivamente, se debruçado sobre a existência e obra do maior compositor nacional até aquela data - ou sequer mencionado algo de sua autoria. Numa época em que a profissão de musicólogo sequer havia tomado forma no Brasil, coube a Porto Alegre, um barão português, começar a esboçar um pouco o retrato de José Maurício, com o tanto de romantismo e idealização concernentes ao seu tempo.

A próxima publicação seria apenas no ano de 1849, quando se deu a catalogação de uma coleção de peças a que o filho de José Maurício - o Dr. José Maurício Nunes Garcia, teria chamado de Mauricinas - que integram a revista Guanabara. Ela saiu do prelo em 1850, dirigida por Porto Alegre, Gonçalves Dias e Manuel de Macedo, e no frontispício lê-se: "Mauricinas: colecção de cançõens e valsas dedicada à Memoria do Pe. Me. Jozé Mauricio Nunes Garcia”. (Porto Alegre et al, 1849, p. 331). Com os matizes adequados à era romanesca, na introdução delineia-se o que se veria até o final do século XX: o uso de figuras de linguagem e de metáforas poéticas para exaltar as qualidades do padre como homem e como compositor: "O raio harmonioso que a Providencia Divina collocara na fronte d'aquelle grande artista, que fez as delicias de El-Rei D. João VI; e exornou os canticos sagrados com innumeras melodias [...]" (Porto Alegre et al, 1849: 332).

Essa mesma perspectiva dominaria a historiografia durante todo o Século XIX e quase todo o Século XX sobre José Maurício. Assim é constituído o artigo "Apontamentos sobre a vida e a obra do Padre José Maurício Nunes Garcia", também de Porto Alegre, publicado na revista do Instituto Histórico e Geográfico Brasileiro, em 1856 (Porto Alegre, 1856), possivelmente o primeiro artigo de que se tem notícia que versa apenas sobre José Maurício. A mesma visão romântica iria nortear outros dois de seus grandes biógrafos, a saber, o Visconde de Taunay (1843-1899) - nobre, músico, engenheiro militar, sociólogo e historiador brasileiro - e Luiz Heitor (1905-1992), musicólogo brasileiro. 
O Visconde de Taunay produziria a mais extensa e completa biografia de José Maurício até o momento, e que por muito tempo foi a fonte quase única para pesquisadores e musicólogos se aprofundarem em sua vida e obra. Sua bibliografia é composta por três obras fundamentais: um pequeno esboceto biográfico, de 1897, que também compôs a introdução à edição do Réquiem para solistas, coro e orquestra do mesmo ano (Taunay, 1897). Em seguida duas obras publicadas no mesmo ano de 1930, postumamente: Dous artistas maximos: José Mauricio e Carlos Gomes e Uma grande glória brasileira José Maurício Nunes Garcia (Taunay, 1930). São livros basicamente descritivos e biográficos, com pormenores folhetinescos - como as brigas palacianas e as supostas querelas entre José Maurício e Marcos Portugal - dando espaço a grandes detalhamentos cênicos e enredos românticos, pouco se atendo aos fatos e às fontes primárias. No entanto, possuem grande valor histórico e científico, tendo sido fonte para muitos trabalhos posteriores, como de Cleofe Person de Mattos, de quem tratar-se-á adiante.

Encontrou-se, ainda, uma pequena biografia anônima redigida a mão, na biblioteca Alberto Nepomuceno da UFRJ, também do ano 1897, de apenas 12 páginas (Biografia, 1897). Meramente enciclopédica, relata alguns fatos em ordem cronológica da vida do padre, e constitui apenas material de curiosidade. Faltam, nessas primeiras biografias, principalmente, referências a fontes, pois as constatações muitas vezes incidem em generalizações ou em suposições como, por exemplo, que José Maurício nos anos antes de morrer chorava compulsivamente - tudo dito de forma bastante idealizada (Biografia, 1897).

O limiar na pesquisa sobre o padre foi, sem dúvida, a obra de Cleofe Person de Mattos (1913-2002), professora da UFRJ, que tem sido considerada a maior estudiosa, coletora e preservadora do acervo de partituras do Padre José Maurício que redundou na publicação do Catálogo temático (Mattos, 1970) e a mais completa biografia do compositor - José Maurício Nunes Garcia-Biografia (Mattos, 1997). Uma fonte fundamental para o conhecimento e entendimento da vida e da obra do Padre músico, tem sido raras vezes abordada do ponto de vista antropológico ou social. A antropologia, que se constitui uma das principais ferramentas metodológicas da Etnomusicologia, é imprescindível para o aprofundamento da pesquisa da ascensão de um músico negro na colônia portuguesa do Brasil.

Entrementes a condução histórica e biográfica que Person de Mattos faz é um tanto mistificada. Ressalta características da vida de José Maurício tendo em vista um detalhamento descritivo e pormenorizado, desde o processo $D e$ genere, que possibilitou que ele se tornasse padre, até sua morte na miséria, e pouco salienta de aspectos socioculturais e antropológicos que tenham redundado em sua delimitação biográfica. Praticamente todos os musicólogos desde Porto Alegre até 
Mattos tratam o padre como portador de qualidades sobre-humanas, como se fora um "Mozart dos trópicos".

Primeiramente, a autora apresenta o cenário propício para o desenvolvimento da narrativa, mostrando um menino nascido em um meio ermo de recursos, neto de uma escrava, que tocava cravo e viola sem ter tido aula. Mário de Andrade

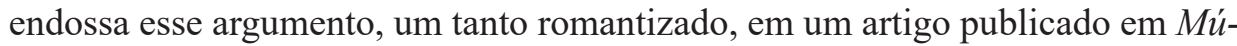
sica, doce música, ao contar que o padre "[...] arranjou uma viola de verdade e a tangeu, tangeu tanto, que acabou descobrindo por si o segredo das primeiras harmonias" (Andrade, 2006 [1933], p. 121). Mas logo em seguida desmistifica um pouco a história, ao dizer que o garoto fora iniciado na teoria musical e no violão em escola do mulato Salvador José, professor mineiro, que havia desfrutado do ambiente colonial de Vila Rica, hoje Ouro Preto, no Estado de Minas Gerais. Deste período surgem as primeiras obras de Garcia, como a Sinfonia Fúnebre (1790), e foi também o ano em que surgiu, mais vigoroso, o desejo de ordenar-se padre, talvez impulsionado pelo falecimento da tia.

O arcabouço desenvolvido por Person de Mattos é unilateral: mostra um pároco músico de origem simples que transmudou-se em um compositor da alta corte aviltado pela mesma. Não nos condiciona, nesse ínterim, a observar o contexto em que nasceu, cresceu e se criou enquanto artista, ou pormenores de sua constituição psicológica, seus prováveis embates contra a sociedade do Rio de Janeiro à sua época, concernentes à sua origem e etnia.

O Brasil carioca dos séculos XVIII e XIX, com suas características específicas, discriminações advindas dos mais variados preconceitos, não aparece, quase, na obra de Mattos.

O que é deveras idealizado, entrementes, em sua biografia, é a representação de um José Maurício Nunes Garcia constituído por habilidades sensacionais, extra-terrenas, e que possuía, simultaneamente, modéstia, simplicidade e submissão. Essa perspectiva é compactuada por outros musicólogos, como Mário de Andrade, que relata um suposto acontecimento em que o próprio Dom João VI teria dito ao padre: “- O padre nunca pede nada!... José Maurício beijou a mão do rei e respondeu: - Quando Vossa Magestade entender que eu mereço, me dará". (Andrade, 2006 [1933], p. 120). A anedota, ainda que reluza bela para um romance, não pôde ser verificada em sua procedência - Mário não cita a bibliografia de onde extraíra o exemplo histórico em questão.

Posteriormente a Cleofe Person de Mattos, houve estudos como os de Cardoso (2008), em que apenas revisita e revisa pontos da biografia feita por ela, em um compêndio descritivo e que não dialoga com possibilidades interdisciplinares, no ramo da História ou Ciências Sociais. 
Os artigos que se constituem delimitadores na historiografia relativamente atual são os de Hazan (2009), Leoni (2010) e Machado (2012), que procuraram contextualizar o chamado "Mulatismo" Musical e suas vertentes historiográficas, contestando o positivismo de Curt Lange, que considerava o amálgama racial benéfico para a concepção musical, e o extremismo de Mário de Andrade - que praticamente desvalorizava a música colonial brasileira enquanto produção artística.

É óbvio que um Padre negro nesse tempo conservaria a humildade e simplicidade noa relação com sua hierarquia superior, todavia o conjunto de lendas disseminadas em muitas obras - como exemplificado pela contenda musical que o padre travara, supostamente, com o compositor português Marcos Portugal (1762-1830) - representam-no como um personagem antes fictício, desprovido de sentimentos e vontades plenamente humanas, dificuldades inerentes ao seu contexto e, mais do que tudo, não questionam, efetivamente: como era ser um padre negro no interior da Igreja Católica no Rio de Janeiro do Brasil-Colônia?

Para responder a essa pergunta recorreremos ao estudo antropológico e histórico por meio do método interdisciplinar da Etnomusicologia.

\section{Metodologia - Etnomusicologia}

Esta pesquisa tem por objetivo realizar uma revisão historiográfica sobre o Padre José Maurício Nunes Garcia (1767-1830), utilizando como principal ferramenta a metodologia da Etnomusicologia, ou seja, a Antropologia e a Sociologia. A Etnomusicologia surgiu como um ramo da Musicologia, em fins do século XIX, vindo a denominar-se como tal apenas em meados do século XX. A princípio era voltada a sanar algumas dificuldades que a Musicologia encontrava, principalmente, no quesito de Metodologia. Tomando emprestados às Ciências Sociais seus métodos, começaram a despontar músicos que se tornaram antropólogos, como o inglês John Blacking (1928-1990).

John Blacking procurou, ainda em 1973, desmistificar a ideia, cristalizada em sua educação, de que a música de concerto erudita europeia ocidental era, por excelência, a mais desenvolvida arte musical de todos os tempos. E conclui que suas concepções, após dois anos de estudos sobre a tradição musical do povo de Venda, no Sul da África, mudaram seus parâmetros drasticamente. Passou a não considerar a tradicional divisão europeia ocidental entre música popular (folk music) e música erudita ou artística (art music), que, para ele, são distinções usadas apenas para difusão comercial. Para ele na Etnomusicologia o estudioso não deveria se ocupar apenas de pesquisa e análise de música exótica ou não ocidental, ou periférica, mas também do estudo de toda manifestação musical e, especialmente, histórica. E argumenta estar “[...] convencido de que uma aproximação antropológica 
ao estudo de todos os sistemas musicais dá mais sentido a eles do que a análise de agrupamentos de sons como coisas em si". (Blacking, 1973, p. 11). Ressalta, ainda, que a música europeia ensinada nos conservatórios não deixa de ser étnica, embora seja de uma etnia específica.

Nessa mesma linha, surgiram defensores de um pensamento que visava à análise da música não mais enquanto produto, mas como processo de um todo, em que estão inseridos aspectos sociais e culturais que redundaram em determinada performance. Como argumenta o etnomusicólogo brasileiro Tiago de Oliveira Pinto:

A etnografia da performance musical marca a passagem de uma análise das estruturas sonoras à análise do processo musical e suas especifidades. Abre mão do enfoque sobre a música enquanto "produto" para adotar um conceito mais abrangente, em que a música atua como "processo" de significado social, capaz de gerar estruturas que vão além dos seus aspectos meramente sonoros. Assim o estudo etnomusicológico da performance trata de todas as atividades musicais, seus ensejos e suas funções dentro de uma comunidade ou grupo social maior, adotando uma perspectiva processual do acontecimento cultural (Pinto, 2001, p. 223).

Ou seja, ao invés de se partir da análise e dissecação do som em si, procurou-se, por meio da Etnomusicologia, inserir em um amplo contexto sociocultural determinada manifestação musical. Para isso são pesquisadas e aprofundadas questões étnicas, sociais e históricas que, provavelmente, tenham ajudado a desenvolver determinadas práticas musicais dentro de determinados contextos.

Em meados do século XIX e durante o século XX acreditava-se na premissa do determinismo, ou seja, que determinados eventos aconteciam não espontaneamente ou devido à sorte ou a outros fatores que independem do homem, mas que toda ação redundava, necessariamente, em uma reação, aludindo à Terceira Lei de Newton. O antropólogo e etnólogo francês Paul Descamps, por exemplo, ao estudar os povos primitivos da Austrália, antes da Etnomusicologia existir, alertava contra o idealismo que, na sua visão, às vezes corre o risco de tangenciar o irreal, e defende o uso do determinismo no estudo etnográfico:

\footnotetext{
O pensamento humano esteve sujeito durante um tempo a uma tendência a qual poderíamos nomear de idealista, uma reação necessária contra os abusos do cientificismo. Isso não significa que devamos fingir que o idealismo não pudesse ser plenamente satisfatório, mas que, do ponto de vista científico, ele poderia incentivar as pesquisas em novos campos, não ignorando que, às vezes, ele tangencia o irreal, o que é um perigo a ser evitado. A ciência deve se manter no campo do determinismo e deixar o resto à filosofia. É um trabalho de sociologia científica o que queremos empreender, não uma tese de meta-sociologia. (Descamps, 1930, p.7).
}

Entretanto, as teses deterministas mostraram-se destituídas de razão ao enfocar as realizações humanas como tácitas e pré-determinadas. Essa noção apenas 
contribuiu para a consolidação do etnocentrismo ocidental altamente enraizado, pelo qual o Determinismo conseguia 'provar', de certa forma, que os negros permaneciam subjugados aos brancos porque era "para ser assim". À luz das experiências da época era por uma vontade divina, ou extra divina, cujas conclusões pseudocientíficas afirmavam serem os cérebros dos negros menos avantajados, o que se demonstrou, mais tarde, ser completamente falacioso.

Dessa forma, pretende-se abandonar quaisquer traços de idealismo e de determinismo nesta tese. Este é um trabalho não-experimental, ou seja, não há envolvimento de dados através da experiência, mas consideram-se grupos sociais, neste caso os escravos negros brasileiros do Século XIX, “[...]"como eles são" e estudamos as supostas influências das variáveis em outras variáveis, as relações entre variáveis". Esta hipótese constitui, portanto, apenas uma aproximação da realidade - não se sabe ao certo como se deu o fenômeno da ascensão social do negro, mas deduziu-se que fatos como o Abolicionismo e movimentos culturais e literários o tenham ajudado a levar a cabo suas aspirações, ainda que não tenham sido determinantes. Far-se-á, assim, um estudo de probabilidades sobre esse fenômeno, considerando o que se escreveu, na historiografia de musicologia e em Ciências Sociais, sobre ele. Obviamente não é possível se afirmar, com propriedade e exatidão, que o fato de um compositor negro mestiço como o Padre José Maurício ter sido alçado ao maior cargo musical da Corte Real significou, necessariamente, que todos os negros e mestiços estavam, simultaneamente, ascendendo a postos e condições melhores de trabalho. Porém não deixa de ser expressivo o número crescente de homens livres a partir do Século XIX, assim como a ascensão de negros a diversas funções antes apenas reservadas aos brancos ou filhos de portugueses. Por isso, podemos argumentar que, provavelmente, as transformações sociais que culminaram na Abolição em 1888 foram precedidas por um fenômeno de pelo menos um século de gradual ascensão negra no Brasil. Como dissertou o sociólogo holandês Fred Kerlinger:

Quando dizemos que "compreendemos" um fenômeno, queremos dizer que conhecemos suas características - pelo menos algumas - o que o produz e quais as suas relações com outros fenômenos. Queremos dizer que tentamos "explicar" o fenômeno. Podemos dizer o que provavelmente o tenha causado, o que influencia agora, o que o influenciará e no que ele influencia. É importante observar aqui que nossa compreensão de um fenômeno é sempre incompleta, parcial e probabilística. Sem dúvida, muito do nosso conhecimento do mundo, especialmente do fenômeno social e humano, é parcial e até falho. (Kerlinger, 1979, p. 5).

O objetivo é investigar se, no percurso da ascensão do negro na sociedade escravocrata do século XIX, o fato de algumas personalidades dessa etnia terem 
despontado seria um reflexo desse movimento, neste caso o Padre José Maurício Nunes Garcia, e se isso contribuiu para a posterior emancipação dos escravos, em 1888. A pesquisa não deve seguir, portanto, os parâmetros apresentados por Descamps, de que seriam fatores pré-determinados - independentes da vontade do Homem que seria, ela mesma, determinada por forças da Natureza às quais ele não tem autonomia - que resultariam nas transformações humanas, mas sim que foi a ação dos homens quem provocou o fim do tráfico negreiro, a derrocada da Escravidão e a consequente libertação do negro. Aposta-se, portanto, no livre arbítrio humano, e não em forças invisíveis de causalidade, ação natural e consequência imediata independentes do desejo dos homens. Pretendeu-se analisar esse processo histórico comparando a bibliografia de sociologia, antropologia com a da incipiente musicologia dos séculos XIX e XX, até os dias de hoje, no Brasil.

Acredita-se ter sido a atuação de indivíduos como o poeta Castro Alves, o escritor Machado de Assis, o escritor e abolicionista Joaquim Nabuco, todos eles negros, que, de certa maneira, exerceram esforços no sentido de desestabilizar a antiga sociedade patriarcal escravocrata dos engenhos. O que se pretende mostrar aqui é que a figura - às vezes eclipsada - do sempre tomado, historicamente, como humilde Padre José Maurício talvez não tenha sido tão impregnada de modéstia e submissão como seus biógrafos desejaram. Não se sabe, realmente, se proferiu as palavras conhecidas da lenda - "se vossa Majestade achar que eu mereço, me dará" - ao Rei Português Dom João VI, tamanha é a infinidade de boatos e histórias inventadas sobre sua trajetória.

O caráter simbólico de sua trajetória - arquétipo representativo da etnia mais abundante no Brasil, o pardo ou mestiço de negro e branco - poderia refletir toda uma passagem da história, já que

[...] a cultura, subjetiva como objetiva, é um conjunto de significados sistematizados, transmitido necessariamente através de símbolos e sinais. [...] a característica básica da cultura é seu caráter simbólico. É essa propriedade da cultura que permite que ela seja transmitida e seja social. (Mello, 1986, p. $48)$.

Dessa forma, poderia se argumentar que os personagens centrais da história seriam espécies de aglutinadores culturais: neles residiriam diversos aspectos de sua sociedade herdados através de séculos, alguns cristalizados, outros ainda em transformação. Ou seja, “[...] o homem cultural é uma criação da cultura, ele é formado pela cultura e todo o seu comportamento é pautado na cultura interiorizada (cultura subjetiva"). (Mello, 1986, p. 49). 
José Maurício Nunes Garcia representaria, ainda, talvez a mais importante expressão musical de seu tempo, no Brasil: não apenas porque em sua obra estão já delineados todos os elementos da música setecentista, colonial e cortesã (a partir de 1808), mas devido à sua inserção num contexto histórico maior. Esse contexto se deu numa configuração histórica que possibilitou a ascensão do Brasil como pátria, provavelmente no intervalo entre a Conjuração Mineira (1789) e a renúncia de Dom Pedro I (1831) (Enders, 2015). Esse período abarca, coincidentemente, a maior parte da vida do padre José Maurício (1767-1830), incitando-se a arriscar que ele possivelmente, se constitui como o primeiro grande símbolo da música nacional brasileira. Além disso, a Historiografia, aliada à Etnomusicologia nos fez entrever a pergunta que norteará o arcabouço desta tese: o padre seria, então, o maior expoente da simbologia histórica musical e, quiçá, artística de seu tempo?

\section{Padre José Maurício Nunes Garcia: arquétipo dum Brasil híbrido}

A nação brasileira sofre, desde sua brutal colonização, dos artificialismos e necessidades concernentes a outra cultura, outra civilização, outro povo, outro clima e outro modo de vida. País continental de extensões até então desconhecidas dos ibéricos, experimentou uma dominação e exploração totalmente arbitrárias - exploração desleixada, carente de método e disciplina - que desconsideraram a sua amplitude, a sua conformidade climática e geográfica completamente díspar dos padrões europeus, o que nos faz sentir até a atualidade essa incompletude nacional, indecisa entre os trópicos e a Europa, tão ou mais confusa e repleta de hibridismos que a própria pátria lusa (Holanda, 2016 [1936]).

Por ter sido formada anteriormente à consumação da raça, a cultura brasileira padece de uma deformação que é perfeitamente congênere à sua história: "Os artistas duma raça indecisa se tornaram indecisos que nem ela". (Andrade, 2006 [1928], p. 11). Num âmbito mais vasto, a cultura reflete apenas o modo de operar da sociedade portuguesa, transportada para o Brasil, e que consiste em uma mistura quase amorfa entre a gente da costa da África e da península ibérica.

A singular predisposição do português para a colonização híbrida e escravocrata dos trópicos, explica-a em grande parte o seu passado étnico, ou antes, cultural, de povo indefinido entre a Europa e a África. [...] o ar da África, um ar quente, oleoso, amolecendo nas instituições e nas formas de cultura as durezas germânicas; corrompendo a rigidez moral e doutrinária da Igreja medieval; tirando os ossos ao Cristianismo, ao feudalismo, à arquitetura gótica, à disciplina canônica, ao direito visigótico, ao latim, ao próprio caráter do povo. A Europa reinando mas sem governar; governando antes a África. (Freyre, 2016 [1933], p. 66) 
A hibridez condescendente e aparentemente sem distinções - a "tara étnica social" do português a que se refere Gilberto Freyre - conjugado a uma suposta falta de disciplina e hierarquia - que condicionou-se a atribuir aos trópicos - teria redundado no Brasil contemporâneo, carente de efetiva subordinação às autoridades e não dado às longas e extensas saudações religiosas, onde o ser amigo é mais importante que o conhecimento, o sentimento compassivo sobreposto ao método, a titulação aristocrática jactanciosa sobre a verdadeira educação (Holanda, 2016 [1936]). Nessa mesma conjuntura ascende uma elite educada cujas bases primordiais eram de festejar um país idealizado (Holanda, 2000 [1959]), estrangeiro à própria cultura, e a convicção de que a técnica sistemática e científica seria aviltante e empobrecedora, já que se assemelharia aos trabalhos braçais - daí a concepção do gênio inato, nascido já dotado de talentos e habilidades sobrenaturais (Holanda, 2016 [1936]), como por vezes nos acaba sugerindo Cleofe Person de Mattos em sua biografia do Padre José Maurício (Mattos, 1997). O divino aspecto que possui o que é importado, alheio à nossa realidade natural, parece ter sempre se sobreposto ao que é realmente nacional; antes é desejável a cultura europeia transmudada e consubstanciada, ou simplesmente copiada, ou a representação de um exotismo ingênuo e descompromissado - que agrada ao olhar estrangeiro e caricatura as idiossincrasias realmente brasileiras (Andrade, 2006 [1928]). Ambas as correntes têm como finalidade em si a negação da verdadeira brasilidade artística: uma porque divulga a perpetuação de uma cultura plenamente europeia ocidental incorporada como nacional; a outra por disseminar uma imagem superficial, metonímica do indianismo e das culturas afro-brasileiras, em que as características dessas culturas são mostradas como se fossem a totalidade do que é a cultura vernácula.

Essas características são plenamente concernentes com a história de escravidão que o Brasil abarca. A massa escrava viu a Independência do Brasil sem sequer ter discutida sua própria independência. Sendo a base de sustentação do Império, a escravidão alimentava a realeza recém-empossada - que de brasileira tinha apenas o nome, já que o próprio imperador era português, e filho do rei lusitano Dom João VI - e a nobreza branca, quase toda portuguesa ou descendente. Tendo doado sua força de trabalho para produzir capital, o negro havia sido alijado do que ele mesmo construíra - não desfrutava da terra que arava e plantava, diuturnamente, por todos os dias de sua vida.

Há, no entanto, uma terceira e importante, imprescindível casta na pirâmide que sustentava a sociedade escravocrata: o clero. Essa alta classe se apossou de suas benesses e defendeu-as ferrenhamente com a teoria de que "tudo era vontade de Deus": os maus-tratos, humilhações e punições, a desigualdade entre raças, a 
desumana vida levada nas senzalas - nada foi contestado, em nenhuma circunstância, pelos sacerdotes.

\begin{abstract}
Entre nós, o movimento abolicionista nada deve, infelizmente, à Igreja do Estado; pelo contrário, a posse de homens e mulheres pelos conventos e por todo o clero secular desmoralizou inteiramente o sentimento religioso de senhores e escravos. [...] ninguém o viu (o clero) tomar a parte dos escravos, fazer uso da religião para suavizar-lhes o cativeiro, e para dizer a verdade moral aos senhores. Nenhum padre tentou, nunca, impedir um leilão de escravos, nem condenou o regime religioso das senzalas. A Igreja Católica, apesar de seu imenso poderio em um país ainda em grande parte fanatizado por ela, nunca elevou no Brasil a voz em favor da emancipação (Nabuco, 2000 [1883], p. 13).
\end{abstract}

Acomodada, assim, com o regime escravocrata, a elite clerical valeu-se de sua retórica para perpetuar a ordem estabelecida, e em seus discursos vemos reproduzida a mensagem de persuasão de que os negros na verdade não eram humanos, e que a sua subjugação e manutenção como escravos era um desejo divino. O romancista José Lins do Rego, que cresceu em um engenho de cana-de-açúcar, em sua obra quase autobiográfica Menino de engenho tece o seguinte depoimento:

O costume de ver todo dia esta gente na sua degradação me habituava com a sua desgraça. Nunca, menino, tive pena deles. Achava muito natural que vivessem dormindo em chiqueiro, comendo um nada, trabalhando como burros de carga. A minha compreensão da vida fazia-me ver nisto uma obra de Deus. Eles nasceram assim porque Deus quisera, e porque Deus quisera nós éramos brancos e mandávamos neles. Mandávamos também nos bois, nos burros, nos matos (Rego, 1987 [1932], p. 134).

Por meio dessa imposição violenta, o negro teve de se aculturar, em passivo sincretismo, à cultura europeia, sendo, além disso, importante disseminador da cultura dominante, mesclando os lusitanismos com o que pouco que restara de sua cultura de origem. Paralisado diante do colonizador, só pôde auferir algum reconhecimento como gente ao lhe imitar os traços culturais: a maneira de vestir-se, de falar e, por que não, de tocar e de cantar - embora no campo musical tenham conseguido, como na culinária, preservar de sobremaneira seus elementos mais característicos Através de uma rígida subserviência e os castigos mais cruéis, forjou-se a desintegração e desumanização dos homens pretos, tratados como bestas de carga e indignos de ter nem mesmo o arbitrário tratamento dispensado aos primeiros trabalhadores a serviço do Capital, na Inglaterra do Século XIX. Como define Darcy Ribeiro:

Submetido a essa compressão, qualquer povo é desapropriado de si, deixando de ser ele próprio, primeiro, para ser ninguém ao ver-se reduzido a uma condição de bem semovente [...]. depois, para ser outro, quando transfigurado etnicamente na linha consentida pelo senhor [...] (Ribeiro, 2015 [1995], p. 89). 
Impossível não fazer, aqui, uma comparação com o Padre-mestre, objeto deste estudo. Se sua obra é, como diria Mário de Andrade, "brasileiríssima" - provavelmente um exagero de Mário - não o é na forma. José Maurício compôs, na maioria de sua obra, missas, motetos e outras peças inspiradas ao modo europeu, principalmente no Classicismo Vienense de Haydn e Mozart. Como o próprio Mário de Andrade argumenta: "esfomeado por música, naturalmente machucado pelo sonho da Europa, desbastava os ordenados na compra de partituras européias" (Andrade, 2006 [1933], p. 125). Suas composições passam longe de lembrar, ainda que infimamente, algum parentesco musical negro, seja coco, maracatu, ijexá, jongo, maxixe, carimbó, entre outras. É de se esperar, entretanto, que assim procedesse - embora fosse um mestiço livre, obviamente pesavam-lhe a etnia e a ascendência africana, e a configuração social da Colônia não era propícia para que houvesse uma valorização da cultura afro-brasileira. Por esse motivo, é compreensível a forma como o Padre digeriu a música europeia, imitando, quase que literalmente, obras de Haydn e Mozart, como se pode sentir ao ouvir o Réquiem, de 1816, praticamente uma homenagem a Mozart. Se fosse apresentada em Viena como obra de Mozart, provavelmente seria tratada como tal - somente um especialista desconfiaria que, na verdade, o Réquiem do Padre é bastante mais modesto e simplificado, praticamente todo construído homofonicamente.

Um artigo do Padré José Geraldo de Souza, já do final da década de 1950, deixa transparecer como a idealização do Padre José Maurício atravessou quase incólume mais de um século após sua morte. Elevando o Réquiem de 1816 ao nível do mozartiano, traça o perfil de um padre-compositor herói, não destoando em nada dos relatos feitos desde o Século XIX até a atualidade. Parece que o musicólogo brasileiro tem dificuldade de criticá-lo ou colocá-lo como um ser humano comum, com características díspares, contraditório e multifacetado. Nas suas palavras:

\footnotetext{
À glória e valor dêste nome singular, não têm correspondido a crítica, a história, o amparo do Govêrno, a divulgação de Sociedades artístico-culturais, fazendo-nos corar perante a queixa de Segismundo Neukomm: (o qual dissera do seu Requiem: "É sublime; só pode vencê-lo o de Mozart”): "Os brasileiros nunca souberam avaliar o bem que tinham..." (Souza, 1957-60, p. 149).
}

A afirmação de Neukomm, se verdadeira ou não, reflete a tendência geral que temos de compararmo-nos sempre com os compositores estrangeiros, particularmente os germânicos, como se só externamente pudessem vir as aprovações e validações do trabalho nacional. Um hábito já antigo e anacrônico, que já o era na época de Mário de Andrade, e que se repete em todas as instâncias da música brasileira - como se travestida de alemã ela pudesse extirpar de si a vergonhosa pecha que autoimpingimos a nós de artistas tupiniquins. 
A obra de José Maurício traduz o espírito da música colonial: a arte coletiva homofônica redundou nas peças do indivíduo, que, por sua vez, refletem o estado das coisas do Brasil de então. Mas como se refletiu esse estado de coisas, dada a intolerância de credo manifesta pelos homens lusitanos, e como isso influiu na música brasileira e, em especial, na música de José Maurício?

A intolerância religiosa portuguesa não poderia afetar o negro do ponto de vista histórico e social - o africano é, em suas raízes, essencialmente religioso e devoto a divindades e, quando inserido na América, especialmente teísta cristão e asceta. Tornou-se tradição que, nos engenhos pernambucanos, os escravos, com o aval de seus senhores, remontassem os rituais de suas nações de origem, reproduzindo os personagens e suas vestimentas, o rei, a rainha, e os deuses de Aruanda. Deuses esses representados como orixás e voduns que, à semelhança das entidades grecoromanas, governam a vida dos humanos na terra.

E se a música brasileira em sua origem foi fruto de uma comunhão entre padres e jovens índios catequizados, ela é plenamente africana no seu conteúdo - o chischibeísmo de que trata Sergio Buarque de Holanda. A sensualidade do negro já se manifesta presente no que é considerado o primeiro gênero de composição musical brasileiro, a modinha, extensamente promulgada além-mar pelo mulato Domingos Caldas Barbosa (1739-1800). Podemos arriscar que ela é, portanto, em suas fontes mais remotas, portuguesa em grande parte, nativa indígena em menor parcela e vastamente africana/parda. No que cabe ao lusitano, vale salientar, altamente jesuítica e ascética, constituindo-se, assim, uma fusão entre o escravo africano e o padre católico português - fusão até então inimaginável. Se a música brasileira é aborígene e lusa nas suas primeiras manifestações, ela é antes negra e mulata, nos seus desdobramentos, do que propriamente descendente de indígenas.

A poesia e a música brasileiras surgiram desse conluio de culumins e padres. Quando mais tarde apareceu a modinha, foi guardando ainda certa gravidade de latim de igreja, uma doçura piedosa e sentimental de sacristia a açucarar-lhe o erotismo, um misticismo de colégio de padre a dissimular-lhe a lascívia já mais africana do que ameríndia. (Freyre, 2016 [1933], p. 222-223).

Com isso há de se concluir que a música brasileira encontrou no amálgama religioso e escravocrata mais um elemento a favor do que contra; o sentimentalismo lusitano aliado à voluptuosidade africana fizeram despontar a modinha e o lundu, que traduzem em música a essência da criação da raça mestiça de negro e branco. Domingos Caldas Barbosa foi a expressão máxima na música colonial do Século XVIII de um hábito que se estenderia por séculos na cultura brasileira - a mistura de elementos culturais de duas classes sociais distintas. A partir dessa 
mistura consolidou-se a modinha como fenômeno raro de disseminação de uma cultura de elite entre as populações mais baixas, formando uma espécie de fusão em que elementos culturais distintos coexistem, o que constitui parte de um processo denominado aculturação. "No processo de aculturação deve haver fusão completa dos grupos de origens diversas, supressão de um grupo ou de ambos, e a persistência dos dois no equilíbrio dinâmico da sociedade". (Lakatos, 1981, p. 133).

Lakatos pontua que há dois processos dentro do fenômeno de aculturação, o de sincretismo e o de transculturação: "[...] no primeiro, há fusão de elementos culturais, dando como resultado um elemento novo (macumba); no segundo, há a troca de elementos culturais (siriós trouxeram o quibe para os brasileiros e adotaram o arroz com feijão)". (Lakatos, 1981, p. 134).

$\mathrm{Na}$ modinha, especificamente, dadas suas características de origem essencialmente de salão e aristocráticas lusitanas, tendo como intérprete, paradoxalmente, um mulato, Domingos Caldas Barbosa, sofreu uma espécie de sincretismo ao entrar em contato com a cultura negra brasileira, particularmente o lundu. Há um momento, em meados do período colonial, que é tão grande a fusão de gêneros, que a modinha se assemelha a uma espécie de lundu lento, e o lundu, a uma modinha acelerada.

A modinha significou, portanto, um fenômeno raro de transformação de paradigma social - nascida na corte lusitana, fora transmudada em música popular urbana, absorvendo e mantendo elementos de linguagens distintas. Esse sincretismo não se traduziu apenas em fatores sociais e culturais, mas também foi marcado por um forte estigma racial - à medida que a modinha aprofundara sua influência negra e parda também levara consigo a discriminação devotada a toda a classe de pretos, incluindo escravos libertos, filhos de escravos e mestiços, mesmo os fisicamente identificados como caucasianos. Não só a modinha trouxe a reboque essa discriminação, como o próprio instrumento que até então era notório em sua execução - o violão. $\mathrm{O}$ violão foi

[...] vencido de tal modo pelo piano inglês de cauda que se tornou vergonhosa sua presença em casa de gente que se considerasse ilustre pela raça e nobre pela classe. Também o violão tornou-se símbolo de inferioridade social e de cultura, arrastando na sua degradação a modinha. Violão e modinha desceram das mãos, das bocas e das salas dos brancos, dos nobres, dos ricos para se refugiarem nas palhoças dos negros e dos pardos, e nas mãos dos capadócios, dos cafajestes, dos capoeiras [...] (Freyre, 1977 [1936], p. 394).

Causa um certo espanto, ainda que prazeroso, saber que José Maurício, pároco negro, resignado ao serviço eclesiástico europeu, tenha tido a coragem auspiciosa 
de se aventurar nesse gênero eminentemente profano, do qual restaram três peças: "Beijo a mão que me condena", "No momento da partida", e "Marília se me não amas - não me diga a verdade". No entanto, é um gênero plenamente mauriciano - visto que o padre começara a estudar música tocando viola de arame e era negro. A modinha seria, destarte, exemplo de fenômeno cultural tanto de aculturação como de deculturação.

O processo de aculturação, já mencionado e explicado acima, e de deculturação, que, segundo Lakatos, ocorre quando há uma dominação de uma cultura sobre a outra, remonta à herança lusitana de contato com o continente africano e às invasões mouras à península ibérica, segundo Gilberto Freyre.

Ao lado dos mouros, afirma Freyre, foram os frades da igreja católica os que mais ofereceram resistência ao poderio econômico judeu - pela sua organização, administração eficiente e propícia à fertilidade de alimentos. A abundância gerada no seio dos conventos parece romanticamente descrita pelo sociólogo: mesas robustas de produtos naturais e frescos, fartura de todos os tipos de legumes e verduras, peixes e caças, ambiente hospitaleiro onde se cantava alegremente enquanto se cozinhavam quitutes, sobremesas e massas. E conclui que talvez a ordem dos frades fosse a classe mais intelectualmente favorecida devido mesmo à tamanha quantidade e qualidade de alimentação disponível, de que careciam as outras classes, “[...] prejudicadas na sua capacidade de trabalho e estudo pela insuficiência alimentar". (Freyre, 2016 [1933], p. 313).

É de se esperar, portanto, que, se o argumento, ainda que um tanto romanesco de $O$ mulato, de que a sociedade (em grande parte) portuguesa, habitante do Brasil do Século XIX repudiava o homem mestiço - contrariando fortemente a conclusão freyriana de miscigenação tolerada e mesmo desejada pelo estrangeiro - fosse em parte verdadeiro, seria natural que um mulato procurasse respaldo nas classes dominantes, especialmente, na Igreja Católica. Sob a crisma católica, pareciam se dissolver as desigualdades raciais e sociais. No português a desigualdade do credo sendo mais execrável que a luxúria e a promiscuidade, constituía a Igreja o refúgio ideal para um homem dito "pardo". Ali ele poderia desenvolver-se plenamente, pelo menos no que cabe à subsistência e alimentação - salientando que o português comum era de praxe subalimentado e desnutrido na época em que estamos tratando. Sob o amparo dos conventos um negro poderia se resguardar de possíveis infortúnios infringidos pela sociedade escravocrata, seria mesmo superior a um homem branco comum, e ainda que pudesse sofrer sendo minoria dentro do clero, estaria parcialmente livre das afrontas sociais e políticas raciais que a dialética Casa-Grande e senzala ainda proliferava, no convento poderia instruir-se e intelectualizar-se, tornar-se parte da classe dominante 
no eixo Portugal - Brasil - a classe clerical. Pode-se dizer que talvez esse tenha sido o contexto vivido pelo Padre José Maurício Nunes Garcia.

Outro fator importante coloca o negro na vanguarda na vida social do Brasil colonial patriarcal: sua superioridade de civilização, importada da África - povo sedentário e agricultor, ao contrário do indígena, nômade. Exercendo sobre o índio ação civilizadora, difundindo a sua cultura entre a dos nativos pôde o negro (os fugidos das senzalas) dominá-la e moldá-la ao seu feitio, aperfeiçoando-a e dotando-a de elementos africanos. Freyre compara a predominância do negro sobre o índio com a do europeu sobre seus povos colonizados:

Pode-se aliás generalizar dos negros fugidos, internados nas matas e nos sertões, que desempenharam todos uma útil função civilizadora: quase sempre elevando a cultura das populações indígenas, raramente deixando-se achatar ou degradar por elas. Diante dos caboclos os negros foram elemento europeizante. Agentes de ligação com os portugueses. Com a Igreja. (Freyre, 2016 [1933], p. 391).

O alto grau evolutivo das civilizações negras possibilitou essa preponderância, bem como a proximidade com o colonizador europeu. Partindo dessa premissa, podemos concluir que o negro, natural e fortemente religioso desde a África adaptou-se ao contexto eclesiástico patriarcal luso-brasileiro e pôde inserir-se de forma contundente na hierarquia da Igreja Católica.

A versatilidade e flexibilidade do negro, no entanto, propiciaram um contexto ímpar de sua situação dentro das estruturas sociais: aliado ao religioso e voluptuoso, ele também desempenhou papel fundamental no incremento da alegria à brasilidade: a jocosidade, o lúdico e o jubiloso cantar dos escravos negros trabalhando - do qual nasceram inúmeros gêneros musicais, como o coco e a embolada - logo invadiu o ambiente antes dominado pelo macambúzio caboclo.

\footnotetext{
A risada do negro é que quebrou toda essa "apagada e vil tristeza" em que se foi abafando a vida nas casas-grandes. Ele que deu alegria aos são-joões de engenho; que animou os bumbas meu boi, os cavalos- marinhos, os carnavais, as festas de Reis. Que à sombra da Igreja inundou das reminiscências alegres de seus cultos totêmicos e fálicos as festas populares do Brasil [...]. (Gilberto Freyre, 2016 [1933], p. 551).
}

E deve ter se impressionado deveras o pequeno José Maurício Nunes Garcia, ao ouvir o canto dos escravos, afirma Mário de Andrade. E logo os começou a imitar - "filho de preto sabe cantar" (Andrade, 2006 [1933], p. 121).

E parece que tinha uma bela voz; da profusão enorme de modinhas, cantos de trabalho e música religiosa profana e no culto, nasceu o mulato, cuja vida e obra se confundem com a história do Brasil. Neto de uma escrava da Guiné, e filho de uma negra mineira com um branco, ele traduz o que pode ter sido o Brasil 
colonial dos Séculos XVIII e XIX: trazia o sangue africano escravocrata, embora fosse livre, era mestiço de branco e negro, e de origem humilde. Ou seja, ele fazia parte da grande maioria da população nacional, um mulato comum. Como pôde esse homem, neto de uma escrava da Guiné, ascender ao maior posto da Igreja para um músico da época - Mestre da Capela Real - e por ele permanecer durante décadas, sendo o principal compositor brasileiro do Século XIX? Para responder essa questão recorreremos à sua ascendência.

Gilberto Freyre ressalta que o negro da Guiné era o preferido para trabalhos domésticos nas Casas-Grandes: com corpos esbeltos e torneados, especialmente as mulheres, eram, no entanto, escravos agrários ruins. A Guiné Portuguesa, hoje Guiné-Bissau, perdeu parte do seu território para a França - o que constitui hoje âmbito da Guiné (francesa). A respeito do povo proveniente dessa região mais a Senegâmbia (atual Senegal), Gilberto Freyre atribui a pele

\footnotetext{
[...] cóbrea avermelhada e cabelos ondeados quase lisos. Os negros desse estoque, considerados, por alguns, superiores aos demais do ponto de vista antropológico, devido à mistura de sangue hamítico e árabe, vieram principalmente para as capitanias, e mais tarde províncias, do norte. Daqui, devem alguns ter emigrado para Minas e São Paulo. Os místicos da superioridade de raça talvez enxerguem no fato explicação das famílias mestiças do Norte e de certas regiões de Minas e São Paulo virem contribuindo para o progresso brasileiro com maior número de homens de talento - estadistas do Império, escritores,bispos, artistas [...]. (Freyre, 2016 [1933], p. 386).
}

Dois fatos dignos de nota: a procedência da avó de José Maurício - Guiné - e o acentuado fluxo de tráfico negreiro desse país para o Sudeste brasileiro, particularmente São Paulo e Minas Gerais, onde nasceu a mãe do padre músico. Isso pode certificar, que a sua origem étnica negra fosse da Guiné, reforçado pela argumentação de Freyre de que talvez os negros oriundos dessa região fossem mais bem-dotados de talentos extraordinários, entre eles, o artístico.

Essa inserção do negro de procedência provável da Guiné no ambiente doméstico do branco

[...] mostra ter havido seleção eugênica e estética de pagens, mucamas e molecas para o serviço doméstico - as negras mais em contato com os brancos das casas-grandes; as mães dos mulatinhos criados e em casa - muitos deles futuros doutores, bacharéis e até padres (Freyre, 2016 [1933], p. 397).

Mais à frente o sociólogo afirma que no Brasil sempre houve mais pressão social (do que em outras colônias europeias) para que o escravo fosse religioso, obviamente católico - dissolvendo e assimilando o paganismo africano no ritual do batizado, ao longo dos anos são "[...] capazes de transmitir às crianças brancas um catolicismo tão puro quanto o que estas receberiam das próprias mães". 
(Freyre, 2016 [1933], p. 437). Com isso queria provar que a influência africana na vida dos culumins não foi, como se é comum colocar, a das doenças venéreas, da sifilização - de que foram muito mais responsáveis os portugueses - ou da voluptuosidade fácil, quente e despudorada dos trópicos. Mas que o negro não foi privado de praticar sua religiosidade original, manteve-a intacta ao contato branco - transformando-a em um catolicismo fervoroso, devoto e submisso. Tão ou mais presente em seu cotidiano que o da beata lusitana mais fanática ou o padre mais fiel; e a partir do acolhimento do negro no centro da Igreja, começou a forjar-se uma nova religião. Nem calvinista nem absolutamente intransigente em seu catolicismo, delineou-se uma Igreja açucarada como os trópicos - onde não há hierarquia entre homens, anjos e santos, onde as festas configuram as cerimônias, há música e júbilo do cantar africano na estruturação primordial da cultura religiosa nacional, fundindo-se ou às vezes mesmo sobrepujando-se à própria lusitana.

A cultura híbrida dos trópicos foi formada à base do contato íntimo entre as mucamas e os filhos brancos do senhor do engenho - através da iniciação, por vezes mesmo prematura, do menino aos jogos sexuais com as negras. Freyre aborda esse convívio quase sanguíneo entre a Casa-Grande e a senzala: convívio permeado por tratamentos sexuais em tenra idade dados pelas amas negras, onde os brancos eram muitas vezes mimados ao exagero pelas mucamas, sendo superprotegidos, "[...] sempre dentro da casa brincando de padre, de batizado e de pais das bonecas das irmãs". (Freyre, 2016 [1933], p. 458). Esse lúdico contexto onde o libidinoso e lascivo é por vezes levado às vias literais da volúpia sexual, onde mistura-se o profano com o religioso, onde as etnias e as classes parecem se diluir na falta de hierarquias bem delimitadas, foi aquele propício para a fomentação de sólidas culturas de sincretismo.

Culturas essas que sobreviveram graças aos mosteiros. No século XVIII, com receio de que a Colônia se desenvolvesse a ponto de rivalizar com a Metrópole em balança comercial, produção de bens de consumo e mesmo culturalmente - já que um povo educado e livre-pensante é sempre uma ameaça aos governantes autoritários, o Marquês de Pombal baixa um decreto, a 3 de setembro de 1759, expulsando os Jesuítas. "Se a treva da ignorância não envolveu totalmente a nossa pobre Pátria nesse triste período, devemo-lo, ainda uma vez, às ordens religiosas, às escolas monásticas mantidas pelos Beneditinos, Carmelitas e, principalmente, pelos Franciscanos". (Heitor, 1950, p. 111). A censura, entretanto, não foi suficiente para conter a desconfiança do colonizador, que, em 1795, é aconselhado a não permitir determinados estudos dentro dos monastérios na Colônia brasileira. 
Luiz Heitor pontua, em seguida, como deve ter sido árdua a educação do Padre José Maurício, em meio tão ermo de recursos intelectuais, onde sofreram, especialmente, os membros oriundos das classes menos favorecidas, com sua "[...] indolência mental, sem estímulos, antes tendo que vencer reais dificuldades para se instruirem". (Heitor, 1950, p. 111.) À parte o aparente preconceito mal dissimulado na afirmação de Heitor - talvez originado na premissa um tanto equivocada de que o brasileiro é naturalmente indolente devido ao clima quente - não deixa de causar impressão o fato de que Portugal realmente coibiu a produção e expressão do pensamento no Brasil, procurando com isso reprimir eventuais arroubos de independência econômica e política que, mais cedo ou mais tarde, acabariam redundando em realidade.

Apesar dessa repressão aos ensinamentos comunitários e a proibição de circulação de livros, parecem ter florescido, ambiguamente, práticas esperadas dentro das contradições naturalmente lusitanas, como já vimos ao longo deste trabalho. Uma dessas práticas parece ter sido o ensino de música aos escravos, ensino esse que seria revertido, aparentemente, no chamado "Conservatório dos Negros" do Rio de Janeiro, cuja existência nunca foi comprovada.

Parece, entrementes, que mesmo antes de embarcar ao Brasil, já recebiam os escravos alguns aprendizados, que principiavam com o batizado e às vezes findavam com a extrema unção, em plenos navios negreiros. Era mister asseverar a saúde do corpo e, uma vez que esta estivesse comprometida, procurar salvar a alma aos negros doentes. Um documento da época narra que um "[...] médico zela por sua saúde corporal e um capelão, pela espiritual. Em regra, todos são batizados antes do embarque, marcando-se com um ferro quente uma pequenina cruz, no peito dos novos cristãos". (Schlichthorst, 1943, p. 130) Isso prova como o africano era conduzido de maneira a aceitar a nova religião imposta, e como era indispensável sempre a presença de um capelão ou frade a bordo do navio negreiro: "Quando morre um negro a bordo, o capitão, os pilotos, o médico e o padre partilham o prejuízo com o dono". (Schlichthorst, 1943, p. 130) A viagem toda é tratada como uma espécie de excursão ao Éden, ou ao Paraíso terreal, visto que ao chegarem nas terras brasileiras os negros de ambos os sexos recebem "[...] um pano azul e um barrete vermelho, pois viajaram em trajes do Paraíso". (Schlichthorst, 1943, p. 131) A crença no Paraíso Terreal era vastamente cultivada pelos ibéricos desde antes da Era das Navegações, através de um germinar constante de lendas fantásticas que criam ser verdadeiras, antes pelo devaneio que por experiências concretas. Essa idealização portentosa, de que trata Sérgio Buarque de Holanda em Visão do Paraíso, e que deu início a centenas senão milhares de elucubrações a respeito de como e onde seria o Éden tropical, parece 
não ter excluído o africano de seus domínios, mas antes o englobado, deglutido e transformado, quiçá pela natureza híbrida do português, e também pela similitude climática entre a África e a América do Sul, o que colocaria ambos os continentes em um lugar avantajado de Paraíso.

Os portugueses, além disso, reforçaram a imagem paradisíaca do Brasil, conferindo mesmo aos escravos um tratamento menos desumano, grosso modo, que em outras colônias inglesas ou alhures; ao batizar e catequisar seus escravos, elevaram-no a status senão similar ao do branco, no mínimo melhor que o cativo das Índias Ocidentais, como observa o viajante militar alemão Carl Schlichthorst: "Por mais dura que seja a um ouvido europeu a palavra escravidão, êsse estado é, na América do Sul, em geral suportavel. O português e o espanhol tratam bem seus escravos [...]". E continua em seguida: "Não são grandes suas necessidades, e seus gosos nada lhes custam". (Schlichthorst, 1943, p. 132) Claro que ele pontua que havia exceções, de senhores que realmente maltratavam os negros, porém a regra geral era antes de aconchego e tolerância - verificada, por exemplo, no fato de que muitas vezes um negro desertor poderia voltar, se se dirigisse a um sacerdote que, comumente, intervia a favor do escravo pedindo ao amo que o perdoasse.

O aspecto principal que caracteriza a aura edênica é, sem dúvida, a alegria do africano. Difícil imaginar um Céu destituído de regozijos - extremamente religioso, o negro dota o culto e seus rituais de júbilo e, incondicionalmente, tem de haver música. E música envolve canto, dança, e toda estirpe de manifestação corporal e terrena possível. Ao contrário da sisudez católica do cantochão medieval em latim, o sorumbático não participa em nenhum momento da liturgia africana ou afrodescendente:

De natureza é o brasileiro melancólico, muito sensual, cerimonioso e desconfiado, qualidades essas que não produzem a verdadeira alegria. A inconsciência do negro deixa-o gosar o que o momento lhe propicia, sem cuidados sôbre o futuro (Schlichthorst, 1943, p. 142).

A sua desvairada alegria invadindo todos os ambientes da colônia, com seus batuques e cantos de trabalho como o bater de cocos que redundou na embolada, o negro foi, dessa forma, importante elemento de formação da base da cultura brasileira e, particularmente, da música. Todos ou quase todos os músicos desde o colonialismo até fins da monarquia no Brasil eram, essencialmente, negros; talvez pelo fato de ter sido sempre considerada uma profissão marginal, braçal e ignominiosa aos olhos do branco dominador. Portanto, proprietário dessa função desde cedo, o preto assumiu, prontamente, a vanguarda da música profana, tendo 
sido responsável, em larga escala, pela criação e difusão dos primeiros e mais importantes gêneros de música popular. E não havia de ser diferente na música sacra; é notável a ascensão do Padre Jesuíno do Monte Carmelo (1764-1819), nosso primeiro padre a se destacar na música colonial, e o primeiro músico de ascendência negra de que se tem notícia, ao lado de Domingos Caldas Barbosa (1739-1800) - este no âmbito da música profana. O Padre Jesuíno surge em um contexto desprovido de elementos que o pudessem fazer galgar uma grande carreira - como José Maurício, era neto de escravos, o que lhe custou a negativa de tornar-se membro da Ordem do Carmo. E vale lembrar que mesmo a admissão ao sacerdócio foi um enorme feito, dado que as leis brasileiras coloniais, derivadas que eram diretamente das portuguesas, coibiam o negro ou mestiço de tornar-se padre, embora tenha-se tornado uma prática comum a aceitação de negros nos templos católicos a partir do Século XIX, “[...] e alguns até, negros retintos". (Freyre, 1933 [2016], p. 502). Fazendo a ponte entre a Terra e o Céu, entre o paraíso terreal e Aruanda, o negro pôde compartilhar diversas características com o colonizador beato, como a fervorosa religiosidade e espiritualidade - o que, no entanto, não o livrou de sofrer preconceitos quanto à sua plena aceitação à frente dos templos ecumênicos.

Assim se deu a conformação ambígua brasileira de tratar os negros, por um lado adotando o costume português de provocar e estimular a sua ascensão social e, de outro, conservando algumas estranhas discriminações dogmáticas, como a recusa de alguns padres e juízes de casar mulher negra com homem branco.

O Padre Jesuíno, artista múltiplo - pintor e músico - terá sido o pioneiro na arte de pintar anjinhos mulatos, quase na mesma época em que o mineiro Antônio Francisco Lisboa, o Aleijadinho (1738?-1814), esculpia seus anjos barrocos mestiços, e um e outro Jesus Cristo mais moreno. Jesuíno ousou, então, adentrar o recinto dos nobres brancos de bata preta:

\footnotetext{
O padre Jesuíno do Monte Carmelo solicitou entrar na Ordem do Carmo! Que escândalo! Afobação assustada dos Terceiros, discussões, defesas ferventes a favor do padre. Padre mas mulato. Como aceita-lo numa Ordem "de pura raça caucásica”, em que só por ser casado "com parda de terceiro grau", sequer um ariano puro podia professar! [...] Mas ou o breve nunca veio ou foi negado, e a vitória de Jesuíno terminou nessa bofetada. Pardo, filho de parda, neto de parda. Negro. (Andrade, 1963 [1945]), p. 66).
}

Os mosteiros e as igrejas, por outro lado, paradoxalmente, constituíam alguns dos poucos lugares onde o negro poderia, se tivesse sorte, galgar a hierarquia e adentrar o recinto da nobreza. Aos poucos foram tomando assento nas cátedras, revestindo-se de mantos e batas, amparados pelos engenhos - a senzala invadindo 
a igreja, e vice-versa. É dessa forma que vemos o engenho colonial brasileiro, impregnado dos ares episcopais sacrossantos, misturar negros e anjos, como na arte colonial.

\begin{abstract}
Nos engenhos jejuava-se e observavam-se os preceitos da Igreja. [...]no dia da botada - primeiro dia de moagem das canas - nunca faltava o padre para benzer o engenho; o trabalho iniciava-se sob a benção da igreja. O sacerdote primeiro dizia missa; depois dirigiam-se todos para o engenho, os brancos debaixo de chapéus de sol [...]. Os negros contentes, já pensando em seus batuques à noite (FREYRE, 1933 [2016], p. 523, 524).
\end{abstract}

Donde se pode concluir que, o engenho e a Igreja tornando-se quase uma única e mestiça propriedade, seria mais fácil para os seus membros se intercalarem, de um para o outro, e assim foi - cada vez mais o negro, obviamente o negro liberto, foi aceito sob o seio católico luso-brasileiro. Assim, os pardos forros e os mestiços em geral faziam pedidos de serem acolhidos no meio eclesiástico, e a (má) experiência do Padre Jesuíno se revela cada vez mais rara - as objeções da Igreja à ordenação são antes de cunho religioso e moral, de verificar se o candidato tem um histórico familiar e pessoal de herege ou não, pouco ou nada inquirindo a respeito da cor da epiderme.

Pelo menos é isso o que mostra o processo de José Maurício Nunes Garcia, de 5 de janeiro de 1791, em que expressa a vontade de ordenar-se padre.

O processo de genere foi instaurado em 5 de janeiro de 1791 por um jovem músico, José Maurício Nunes Garcia, que assim concretizava o desejo de "entrar em ordens". O processo - cujo objetivo era colher informações acerca dos hábitos religiosos de seus ascendentes, especialmente se batizados, se haviam sofrido "pena vil" ou acusação de heresia - fazia-se através de documentos e depoimentos de testemunhas chamadas a prestar, sob juramento, as informações necessárias. (Mattos, 1997, p. 18).

Logo vê-se que a preocupação da Igreja era, como já salientamos, antes herético que eugênico. Entretanto o romance do Mulato deve ter tido sua significação histórica, ainda que seja um pouco exagerado. Parece sim que tamanha população descendente de português e negro, majoritariamente, e indígena, minoritariamente, maculasse preconceitos arraigados e inerentes a ela: o preconceito de cor não era apenas uma conjetura. Embora considere que a união de brancos afidalgados e negras tenha criado uma prole das mais robustas e inteligentes das Américas, Gilberto Freyre conclui:

Sob a pressão desses preconceitos desenvolvem-se em muito mestiço evidente complexo de inferioridade que mesmo no Brasil, país tão favorável ao mulato, se observa em manifestações diversas. Uma delas, o enfático arrivismo dos mulatos, quando em situação superior de cultura, de poder ou de riqueza. Desse inquieto arrivismo podem-se salientar duas expressões características: Tobias Barreto 
- o tipo do novo culto [...]; e na política, Nilo Peçanha. Por outro lado, ninguém mais reticente que Machado de Assis. (Freyre, 1933 [2016], p. 537).

E seria, também, o Padre José Maurício Nunes Garcia, figura tão ou mais reticente que Machado de Assis, em sua discrição humilde e acanhada, sua subserviência quase humilhante, como definiu Mário de Andrade.

O seu grande mérito, no entanto, talvez resida na ascensão que ele representa. O valor pelo qual um escravo era vendido, desde o Século XVII até o XIX, aos comboeiros girava em torno dos "100\$000, os melhores, a 120\$000". (Freyre, 1977 [1936], p. 14). De acordo com Sombra (1938), no Século XIX, sob a regência de D. João VI, um Tostão de prata valia 100 réis, e seis vinténs de prata, 120 réis.

O Padre José Maurício, segundo Azevedo (1861), em 1798 tinha ordenado de 600 réis, valor que, teoricamente, poderia comprar seis escravos por mês, se levadas em conta as informações que Freyre nos fornece. Dadas as devidas proporções, não deixa de ser um salário bastante próspero para um negro neto de escravos, à época. Azevedo (1861, p. 39) ainda reitera:

"Por decreto de 26 de Setembro de 1803 foi nomeado inspector da musica da real Capella com o ordenado de $600 \$$ rs. E foi sempre esse o ordenado que recebeu dos cofres públicos [...]". Embora nos pareça realmente um generoso ordenado, não é possível ter a exata dimensão do que seriam, por alto, esses 600 réis hoje. O fato é que Azevedo pondera que, apesar dessa retribuição mensal, o Padre sempre viveu muito pobre, a ponto de não conseguir comprar um cravo - sempre obrigado a lecionar com uma viola de cordas de arame.

Um estudo da Unicamp ${ }^{1}$ aponta que o salário do Sargento Mor Comandante da tropa de linha da Província Ceará em 1820 recebia 300 réis mensais. Ou seja, o padre ganhava o equivalente a dois sargentos comandantes - o que, novamente, parece ser uma quantia bastante razoável. O mesmo estudo informa, ainda, que em 1821 um exemplar do jornal Diário do Rio de Janeiro custava 40 réis. Comparando com o preço dos jornais atuais - o Jornal carioca $O$ Globo custa $\mathrm{R} \$ 4,00$, o mesmo preço do paulistano $O$ Estado de S. Paulo - calculando a proporção o ordenado de 600 réis do Padre seria de aproximadamente $\mathrm{R} \$ 60,00$, ou seja, nada que ofereça bases sólidas reais. No entanto o fato de que constituía uma quantia o dobro da recebida por um militar graduado e comandante é significativo - e também por ser um valor que poderia, talvez, comprar escravos.

1. Disponível em: http://www.unicamp.br/iel/memoria | http://www.unicamp.br/iel/memoria/base_temporal/Numeros/ | Acesso em: 28.06.17, às 22:00 hrs. 


\section{Conclusão}

Sob essa perspectiva, pode-se dizer que o Padre representou uma rara ascensão dentro de sua etnia e condição social primeira, dentro da história do Brasil Colônia. Deteve o melhor posto para a posição de músico brasileiro, Mestre da Real Capela, impulsionado, obviamente, pela sua ordenação como padre, e todo o aparato da igreja, sem o qual provavelmente não haveria concebido tão grandes feitos.

Ele pode representar, por outro lado, o arquétipo desse país continental, que até a atualidade é subserviente a negócios estranhos aos seus, que se desenvolveu reproduzindo os padrões culturais de outras terras e de outra gente. País que desde a formação não se formou, permanecendo embrionário, abarcando todas as raças e não comportando nenhuma, mostrando como

\footnotetext{
[...] uma nação pode constituir-se não para servir a si mesma, mas para atender a interesses alheios. Efetivamente, o Brasil não nasceu como etnia e se estruturou como nação em consequência da soma dos desígnios de seus criadores. Surgiu, ao contrário, como uma espécie de subproduto indesejado e surpreendente de um empreendimento colonial, cujo propósito era produzir açúcar, ouro ou café e, sobretudo, gerar lucros exportáveis. Desse empreendimento [...] resultou ocasionalmente um povo e, mais tarde, uma sociedade nacional. (Ribeiro, 1978, p. 19).
}

O Padre realmente atendeu aos desígnios de sua pátria. Mestiço, oscilando entre as raças, agarrou-se ao clero para livrar-se da penúria que, no entretanto, o acompanhou até a morte. Compôs uma vasta obra musical em que atendia apenas aos desejos de seus superiores - daí ser uma obra basicamente homofônica, e com algumas exceções consonante, clara, simples e pouco individualista, como lembra Mário de Andrade (2006 [1933]).

Passou à história, portanto, antes como o padre negro que empreendeu o enorme feito de ter sido nomeado Mestre da Real Capela, do que pelas composições que legou à mesma. Compositor claramente alinhado ao Classicismo vienense, pouco inovando na estrutura e na forma, a ponto de algumas de suas peças, como a missa de Réquiem de 1816, terem uma semelhança quase idêntica a peças de Mozart. Um pároco que teve filhos, mestiço que viveu entre os brancos, solícito e conformado, procurando agradar a trupe de uma realeza lusa fugida, temerosa de Napoleão, decadente e ainda absolutista.

Sua obra assimilou a cultura dominante estrangeira, e ainda que tenha caráter inconfundivelmente nacional (Andrade, 2006 [1933]) expressa o paradoxismo pessoal de Nunes Garcia: um mestiço que trabalhava sob o jugo do Rei português, e que teve a seu favor a ordenação eclesiástica, a competência equilibrada e a falta de ambição. Curvado a esse rei, beijou a sua mão, conforme reza a lenda, 
mesma mão que o condenaria - talvez não deliberadamente - ao ostracismo e a miséria no fim da vida.

\section{Referências}

Andrade, M. de. (2006 [1933]). Música, doce música. Belo Horizonte: Itatiaia. . (2006 [1928]). Ensaio sobre a música brasileira. Belo Horizonte: Itatiaia. . (1963) Padre Jesuíno do Monte Carmelo. São Paulo: Martins.

Azevedo, A. de. (2013. [1881]) O mulato. Porto Alegre: L\&PM.

Azevedo, M. de. (1861) Ensaios biographicos. Rio de Janeiro: F. A. de Almeida.

Biografia do Padre José Mauricio Nunes Garcia. (1897) Rio de Janeiro: [s.n.]. 12 p.

Blacking, J. (1973). How musical is man? Washington: Washington Press.

Cardoso, A. (2008) A música na corte de D. João VI. São Paulo: Martins Fontes.

Cunha, E. da. (2016 [1902]).Os sertões. Rio de Janeiro: Nova Fronteira.

Descamps, P. (1930). État social des peuples sauvages. Paris: Payot.

Enders, A. (2015. [2000]) A história do Rio de Janeiro. Tradução de Joana Angélica D'ávila Melo. Rio de Janeiro: Gryphus.

Forbes, J. (1993) Africans and Native Americans: the language of race and the evolution of Red-Black people. Illinois: University of Illinois.

Freyre, G. (2016. [1933]) Casa-Grande e senzala. São Paulo: Global. . (1977. [1936]) Sobrados e mucambos. Rio de Janeiro: José Olympio

Hazan, M. C. (2009) Raça, Nação e José Maurício Nunes Garcia, Resonancias: Revista de investigación musical, vol. 13, n. 24, p. 23-40.

Heitor, L. (1930).O espírito religioso na obra de José Maurício. Ilustração Musical, n.3, p. 75-8. . (1950) Música e músicos do Brasil: História-Crítica-Comentários. Rio de Janeiro: Casa do Estudante do Brasil.

Holanda, S. B. de. (2016. [1936]) Raízes do Brasil. São Paulo: Companhia das Letras. . (2000 [1959]).Visão do Paraíso. São Paulo: Brasiliense

Kerlinger, F. N. (1979). Metodologia da pesquisa em Ciências Sociais: um tratamento conceitual. Tradução de Helena Mendes Rotundo. São Paulo: Pedagógica e Universitária.

Kerr, D. Vaccari, P. R. (2019). The Hegemony of the Europeanism in the Work of José Mauricio Nunes Garcia. Journal of Ethnomusicology, vol. 3, n.1, p. 117-127.

Lakatos, E. M. (1981) Sociologia geral. São Paulo: Atlas.

Leoni, A. L. (2010) Historiografia musical e hibridação racial. Revista Brasileira de Música, Rio de Janeiro, v.23, n.2, p. 95-119.

Machado, D. N. (2012) O “mulatismo musical”: processos de canonização na historiografia musical brasileira. In: Música, Discurso e Poder. Minho: Universidade do Minho, p. 287-308.

Mattos, C. P. de. (1970) Catálogo temático: José Maurício Nunes Garcia. Brasília: Conselho Federal de Cultura. 
(1997) José Maurício Nunes Garcia: Biografia. Rio de Janeiro:

Biblioteca Nacional.

Mello, L. G. de. (1986). Antropologia cultural: Iniciação, teoria e temas. Petrópolis: Vozes.

Nabuco, J. (2000 [1883]). Abolicionismo. São Paulo: Publifolha.

Pinto, T. de O. (2001) Questões de antropologia sonora. Revista de Antropologia, São Paulo, v. 44 , n. 1, p. $221-86$.

Porto Alegre, M. de A. (1836) Ideias sobre música. Revista Nitheroy, Paris, 1(1), p.160- 183. et al. (1850). Mauricinas: colecção de cancõens e valsas dedicadas à Memoria do Pe. Me. Jozé Mauricio Nunes Garcia. Revista Guanabara, Rio de Janeiro, tomo 1, p. 332-334.

(1856) Apontamentos sobre a vida e a obra do Padre José Mauricio

Nunes Garcia. Revista do Instituto Histórico e Geográfico Brasileiro, Rio de Janeiro, tomo XIX, p.354-69.

Rego, J. L. do (1987 [1932]). Menino de engenho. Rio de Janeiro: Nova Fronteira.

Ribeiro, D. (1978). Os brasileiros: 1. Teoria do Brasil. Petrópolis: Vozes. . (2015 [1995]). O povo brasileiro: a formação e o sentido do Brasil. Rio de Janeiro:

Global.

Schlichthorst, Carl. (1943) O Rio de Janeiro como é. 1824- 1826. (Huma vez e nunca mais). Tradução: Emmy Dodt e Gustavo Barroso. Rio de Janeiro: Zélio Valverde.

Sombra, S. (1938) História monetária do Brasil colonial. Rio de Janeiro: Laemmert.

Souza, P. J. G. de (1957-60) História da composição sacro musical no Brasil. Revista do Conservatório Brasileiro de Música, Rio de Janeiro, ns.9 a 20, p. 143-164.

Taunay, V. de. (1897). Esboceto biográphico. Rio de Janeiro: s.e.(?). . (1930) Dous artistas maximos: José Mauricio e Carlos Gomes. São Paulo: Melhoramentos. (1930). Uma grande glória brasileira José Maurício Nunes Garcia. São Paulo: Melhoramentos, 1930.

Vaccari, P. R. (2018) Padre José Maurício Nunes Garcia e o mulatismo musical: embranquecimento histórico? Revista Música da USP, São Paulo, v. 18, n. 1, p. 170-85.

Data receção: $12 / 09 / 2019$

Data aprovação: 18/05/2020 